\title{
Implementation of Military Emergency in Indonesia to Handle Corona Virus Disease (Covid -19) in the Perspective of Human Rights
}

\author{
Yoan Barbara Runtunuwu* \\ Law Studies Program \\ Faculty of Social Sciences, \\ Universitas Negeri Manado \\ Manado, Indonesia \\ yoanruntunuwu@gmail.com
}

\author{
Stince Sidayang \\ Law Studies Program \\ Faculty of Social Sciences, \\ Universitas Negeri Manado \\ Manado, Indonesia \\ vsidayang45@gmail.com
}

\begin{abstract}
Indonesia as a big country in the early 2020s has experienced various disasters, include those the most serious attention from the Government of the Republic of Indonesia to handle the spreading of Corona Virus disease or COVID -19. If no immediate steps taken are supposed to be feared threats political stability, Economic, Social, National Defence. The President of the Republic of Indonesia stated Indonesia has infected by Corona Virus disease or COVID-19. Emergency Disaster after obtaining accurate information from the World Health Organization related to COVID-19 dated March 11, 2020, as a pandemic according to the number of death and spread quickly coupled with the experience of the first Pandemic country COVID-19 such as China, Italy, France, America and other countries in the world who are facing the pandemic. Dealing with COVID-19, the efforts made by law enforcement agencies are limiting social distance and not to leave the house, but this will have fatal consequences if not explicitly handled, within one month or two months still be overcome properly, but if the spreading of COVID cannot be stopped for the next seven months, it will harm Indonesia, where there is a large-scale panic, for a group of people will looking for food by looting the economic center. It is necessary to conduct martial law immediately to handle completely and quickly.
\end{abstract}

Keywords: Enforcement of martial law, handling Corona Virus, Human Rights Perspective

\section{INTRODUCTION}

Indonesia since declaration co-19 disaster emergency is still struggling against the Coronavirus, the same as other countries in the world. The number of cases of the Coronavirus continues to grow with several reports of recovery, but not a few have died. Handling and prevention efforts continue to be made to fight COVID-19 with flu-like symptoms. The Coronavirus case was discovered through a mysterious illness that paralyzed Wuhan City, China. The tragedy at the end of 2019 continued until the spread of the Coronavirus spread throughout the world.

The Republic of Indonesia is a statutory state based on the 1945 Constitution which upholds human rights as well as guarantees all citizens are equal in the status of law and government and should uphold the law and government without exception [1]. The rule of law rests on the belief that state power should be exercised based on fair and good law. The relationship between governed and the governor is run based on an objective norm, not on absolute power. These objective norms should meet formal requirements and can be defended by legal ideas [2].

According to Theo Huijbers, the aim of political law is not only to guarantee justice but also to create peace of life, by maintaining legal certainty. Legal certainty is not a legal (political) goal, but rather it is something that should exist if justice and order are to be created. It seems impossible to create justice and peace if legal certainty is not maintained [3].

Background on the Coronavirus or COVID-19, the case began with pneumonia or mysterious pneumonia in December 2019. This case is thought to be related to the Huanan animal market in Wuhan that sells various types of animal meat, including those that are not commonly consumed, such as snakes, bats and various types of mice.

Cases of this mysterious pneumonia infection are indeed commonly found in the animal market. Corona or COVID-19 virus is thought to be carried by bats and other animals that humans eat until transmission occurs. Coronavirus is no stranger to the world of animal health, but only a few types can infect humans to become a pneumococcal disease. Before COVID-19 became epidemic, the world had a stir with Sars and Mers, which was also related to the Coronavirus. With this background, the Coronavirus is not the only time this makes people in the world panic. Having the same flu-like symptoms, the Coronavirus develops rapidly to result in more severe infections and organ failure. The President of the Republic of Indonesia Ir.Joko Widodo has called on citizens to focus more on activities at home. A step to respond to the Corona COVID-19 Virus pandemic. "It is time for us to work from home, learn from home, worship at home.

This is the time to work together to help and unite with each other cooperation," said President Jokowi on March 15,2020 . Not only Indonesia, but a social appeal is also being encouraged issued in several countries, such as Australia, New Zealand. As quoted by ABC Indonesia, 
Australian Prime Minister Scott Morrison, followed by leaders of states, has implemented. Is including banning events and gatherings involving 500 people. Social distancing efforts need to be understood as a form of prevention of COVID-19 transmission, in addition to reducing the burden on public health services.

The definition of 'social distancing' is to reduce the amount of activity outside the home and interaction with others is considered capable of reducing direct face-toface contact. This step includes avoiding going to places which are crowded, such as supermarkets, cinemas, and stadiums. When implementing social distancing, health authority agencies in the state of New South Wales (NSW Health), Australia, going to the office or using public transportation are still allowed. However, we should maintain a distance of at least 1.5 meters from others, even though health experts say this cannot be applied in all situations. Those who choose this method as a precautionary measure also need to avoid social events, such as gatherings with family or friends, including weddings.

Direct physical contact, such as shaking hands, hugging, and kissing should not be done, because the Coronavirus spreads through 'droplets', or droplets of saliva. The social distancing method has been implemented in Wuhan City, Hubei Province, China, where the Coronavirus originated. As the epidemic broke out, health authorities in China quickly banned events that were attended by large numbers of citizens. Therefore, there is a decreased rate of transmission, compared to Iran and Italy, where the government has not issued a 'social distancing' appeal. Not only social distancing, but Wuhan Province also applies strict lockdown. But in other countries, lockdowns do not necessarily succeed in suppressing the rate of spread of the virus.

\section{RESEARCH METHODS}

The method used is normative legal research. This legal research is conducted to produce new arguments, theories or concepts as perspectives in solving problems faced, the expected answers in research are true, right or wrong. It can be stated the results obtained in legal research already contain a value [4]

Legal research is a scientific activity which is based on certain mathematical methods and ideas aimed to study one or several specific legal phenomena, by analyzing them [5].

By explaining the history and making comparisons, by using primary and secondary database material, the primary and secondary data material cannot be separated from the legal developments occurred in various circles in society, then using a positivist approach where the cause determines the impact; begins by collecting data provided by government or private institutions related to handle Corona Virus or COVID-19. In Indonesia and its development, then analyzing primary and secondary data to produce data that illustrates the things affected the ineffective handling Coronavirus in Indonesia. The theory used is a state responsibility and human rights, this research method analyzes the effectiveness of handling Co-19, this research has the main focus by paying attention to the social effects of distancing and martial law as a quick solution to handling the spread of Co-19.

\section{RESULTS AND DISCUSSION}

The distribution of the coronavirus is massive, reaching 17 provinces in Indonesia. The government is working hard to limit the spread of the virus and deal with the people affected by COVID-19. The readiness of the government to create responsive policies related to the devotion of doctors and medical personnel is certainly worthy of appreciation. The nation's problems regarding the dangers of coronavirus disease 2019 (COVID-19) certainly require further stance. Reflecting on the success of China, the progress of Italy, and the strategic steps of various countries, Indonesia needs to think of an anticipatory policy based on the sustainability to handle COVID-19. Estuary of this thought is the determination and alertness of all elements to overcome the danger of COVID-19, to handle COVID-19 is the unity of action was born from a comprehensive strategic policy.

This policy should address the current conditions and anticipate their impact later. Community Safety and security should be guaranteed and not just be a subject of debate. There are three policies needed to be synergized due to COVID-19 to ensure survival. First, policies that strengthen the availability and reliability of the COVID19 handling infrastructure. It is seen, the efforts of the government and the professionalism of the vanguard of health can be called the foundation of handling COVID19. Although they have not been able to stop the spread of the virus, the readiness of the government and medical personnel has proven to be able to inhibit and localize the spread. The foundation for handling COVID-19 needs to be expanded and strengthened.

The alertness, professionalism, and volunteerism of the 'soldiers' of health should be balanced with the same health and safety guarantees. Efforts to minimize risk need to be accompanied by adequate personal protective equipment (PPE) and qualified medical equipment. The availability of the hospital and its handling capacity should be able to handle the explosion of patients in the area. Second, the policy to conduct COVID-19 danger education for the entire community, especially the lower middle class. Assuming the middle and upper classes can 'secure' themselves, social education is needed by the middle and lower classes.

The complexity of social education will tend to thicken because the problems of community life in Indonesia are unique. Although this looks easy, in reality, it is not simple. To the extent there is no appropriate social education policy, the anxiety and panic of the middle to lower classes will continue. Uncontrolled information about COVID-19 and the failure of persuasion to break the chain of distribution reflects the absence of changes in attitudes and behavior. If this continues, functional impacts will also not work for co-19 hazard education. Besides, the communal nature and patterns of livelihood often negate the applied steps of social education.

The COVID-19 social education policy should be formulated systematically without causing public unrest and panic. The aim is to prepare the community to face the danger of COVID-19 intelligently and wisely, as should education on how to deal with natural disasters. 
Only with this social education policy COVID-19 control be conducted, given the largest proportion of potential carriers is in the middle to lower classes of society. Third, the national policy to mobilize the industry to participate to face COVID-19. The involvement of the national industry was done by asking them to temporarily massproduce COVID-19 prevention, inspection and handling equipment. 'Mimicry' of such an effort is directed to the availability of masks, sanitizers, PPE, and food for those who are vulnerable to these primary needs. Transferring temporary efforts to produce goods and food is certainly not difficult if the national industry prioritizes sensitivity to the real needs of the community.

Consequently, the policy asking for industry participation needs to be accompanied by other policies that lead to economic stimulus. This means stimulus should be able to activate the urgency in helping to deal with COVID-19, provide an appreciation for the assistance provided, and be a way for the government to pay back for industrial sacrifice. If the three policies above are synergized, to handle COVID-19 certainly be maximized. The synergy of this policy does not merely become a short-cut handling of hazards but also leads to strengthening the firmness and alertness of the nation's elements in handling COVID-19.

The Formation of the Task Force for COVID-19 Handling Acceleration was a significant step in overcoming COVID-19. In addition to synergizing the acceleration measures, this task force needs to pay attention to the policy synergies above. The thing that should be prioritized is to 'oversee' the acceleration and implementation of policies to the regions to create a unified action in handling COVID-19. As for the Presidential Decree No. 7 of 2020 concerning the Task Force for the Acceleration of Corona Virus Disease 2019 (COVID-19) is: (Presidential Decree of the Republic of Indonesia Number 7 of 2020 dated March 13, 2020, n.d.)

1. The spread of Corona Virus Disease 2019 (COVID19) in the world tends to continue to increase from time to time, cause greater loss of life and material losses, and has implications for social, economic, and social welfare aspects,

2. The World Health Organization (WHO) has declared COVID-19 as a Pandemic on March 11, 2020,

3. There have been certain circumstances with the presence of COVID-19 transmission in Indonesia need to be anticipated for their impact,

4. In the framework of accelerating the handling of COVID-19, quick, appropriate, focused, integrated, and synergic steps are needed between ministries/agencies and local governments,

5. Based on the considerations as referred to in letter a, letter $\mathrm{b}$, letter $\mathrm{c}$, and letter $\mathrm{d}$, it is necessary to stipulate a Presidential Decree concerning the Task Force for the Acceleration of Handling Corona Virus Disease 2019 (COVID-19);

The legal basis for establishing Presidential Decree 7 of 2020 concerning the Task Force for the Acceleration of Corona Virus Disease 2019 (COVID-19) is:

1. Article 4 paragraph (1) of the 1945 Constitution of the Republic of Indonesia;

2. Law Number 4 of 1984 concerning Communicable Diseases (Statute Book of the Republic of Indonesia
Number 20 of 1984, Supplement to Statute Book of the Republic of Indonesia Number 3273);

3. Law Number 24 of 2007 concerning Disaster Management (State Gazette of the Republic of Indonesia of 2007 Number 66, Supplement to the State Gazette of the Republic of Indonesia Number 4723);

4. Law Number 36 of 2009 concerning Safety (State Gazette of the Republic of Indonesia of 2009 Number 144, Supplement to the State Gazette of the Republic of Indonesia Number 5063);

5. Law Number 6 of 2018 concerning Health Quarantine (State Gazette of the Republic of Indonesia of 2018 Number 128, Supplement to the State Gazette of the Republic of Indonesia Number 6236);

6. Presidential Regulation Number 17 Year 201B concerning Disaster Emergency Management in Certain Conditions (State Gazette of the Republic of Indonesia 2018 Number 34);

The formation of the Task Force for the Acceleration of Corona Virus Disease 2019 (COVID-19) for the next in this Presidential Decree is called the Task Force for the Acceleration of Handling COVID-19. The Task Force for the Acceleration of Handling COVID-19 is under and is responsible to the President.

The Task Force for the Acceleration of Handling COVID-19 aims:

1. increase national resilience in the health sector;

2. accelerate the handling of COVID-19 through synergy between ministries/institutions and local governments;

3 . increase the anticipated development of the escalation of the spread of COVID-19;

4. increase the synergy of operational policy-making; and

5. increase readiness and ability to prevent, detect and respond to COVID-19.

Implementing the Task Force for the Acceleration of Handling COVID-19 as referred to in Article 4 letter b has the following tasks:

1. establish and implement an operational plan for the acceleration of handling COVID-19;

2. coordinating and controlling the implementation of the acceleration of COVID-I9 handling activities;

3. supervises the implementation of the acceleration of handling of COVID-19;

4. mobilize resources for the implementation of the acceleration of COVID-19 handling activities; and

5. report the implementation of the acceleration of handling of COVID-19 to the President and Director.

The Chief Executive of the COVID-19 Task Force for the Acceleration of Handling prepares and submits daily routine reports to the President and Director.

The Chair of the COVID-19 Task Force for the Acceleration of Handling Acceleration reports urgent events to the President and Steering at any time if necessary.

- Governors and Regents / Mayors form the Regional Task Force for the Acceleration of COVID-19 Management based on the considerations and recommendations of the Chairperson of the Implementing Team for the Task Force for the Acceleration of COVID19 Handling.

- Handling of COVID-19 in the regions was conducted due regard to the direction of the Chief Executive of the Task Force for the Acceleration of Handling COVID-19. 
Implementing the Task Force for the Acceleration of Handling COVID-19 conducting their duties may involve and/or coordinate with ministries / non-ministerial government agencies, central and regional government agencies, the private sector, and other parties deemed necessary. Funding needed for the Task Force for the Acceleration of Handling COVID-19 is charged to the State Revenue and Expenditure Budget, Regional Revenue and Expenditure Budget, and/or other legal and non-binding sources by statutory provisions.

\section{Enforcement of social distancing and physical distancing in Indonesia}

Physical distancing is a substitute term for social distancing, which both aim to prevent coronavirus. tirto.id - President Joko Widodo emphasized physical distancing for handling and preventing the COVID-19 coronavirus in Indonesia. Physical distancing can be translated by keeping a distance or keeping a safe and disciplined distance to be conducted, as quoted from the Cabinet Secretariat website. "Keep this distance not only applies in public places but also applies to all households in every family.

Because all families are not necessarily negative, it is not certain that all family members are safe from this Corona Virus, "said the Head of the National Disaster Management Agency (BNPB), Doni Monardo, delivering the results of the meeting with Jokowi. The term physical distancing is not only applied in Indonesia but also in Canada. Canadian health experts and politicians have urged residents to keep their physical distance from each other and stay home as often as possible to help stop the spread of the coronavirus. Prime Minister Justin Trudeau said there was no tolerance for those who opposed physical distancing orders and the government could introduce measures to enforce health warnings. "You all think you are invisible. You are wrong. That's enough," he said in his address to Canadians from Rideau Cottage, where he was isolated. "Go home and stay home." Deputy Prime Minister Chrystia Freeland and chief public health officer Dr. Theresa Tam echoed physical distancing during a ministerial-level press conference shortly after Trudeau spoke with reporters. "Canadians should practice social and physical distance," Freeland insisted. "That means staying at home unless you do important work like guarding a grocery store., staff pharmacies staff and provide medical care, "as quoted by Global News Canada.

What is Physical Distancing? Physical distancing is increasingly being used to help people understand what they need to do to prevent COVID-19 transmission. "We started with the term 'social distance' social distancing and I think some people don't understand the meaning, and they worry that it causes social isolation.

That social distance as described in practice is still felt to be weak and this has an impact on the increasing number of people infected with the COVID-19 Virus and dying. Various attempts have also been recommended including washing hands frequently, changing clothes when active, not greeting, kissing in the context of hospitality. and clean culture still seems to be weakly implemented in a disciplined manner this is what raises fears of the increasingly widespread co-19 pandemic. Law enforcers in carrying out their actions are often influenced by certain factors. Some of these factors, such as legal factors, law enforcement factors, factors or facilities, community factors, and cultural factors (Soekanto, 1983)

\section{Martial Law, against the handling of the COVID-19 disaster in Indonesia.}

Martial law is a set of regulations that are effectively enforced (usually after an official announcement) after the military authority has taken over power from an officially ruling government. Martial law is often imposed when military activity is felt to be very necessary, usually for anything urgent, where the ruling government cannot function properly or is felt to be too slow or too weak to deal with these situations; for example due to war, natural disasters, civil disorder, in the realm of power,

In overcoming Corona Pandemic, the Indonesian government does not have to implement a lockdown system. The Government of Indonesia in dealing with threats and emergencies can implement several options as the context, scale, and form of threats. Efforts to deal with COVID-19 in Indonesia are currently unstructured and seem chaotic. This condition can be seen from the maze of information, treatment of patients and suspects are not measured and directed to the irregular conditioning of people's lives. The government currently applies to learn for students and workers working from home for 14 days. The application of this policy was conducted as an effort to prevent the spread of co-19 by restricting the activities of many people in the public sphere. But in reality, the work from the home policy of 14 days is used by some people for holidays and among students instead, they hang out and travel like the school holidays. This is exacerbated by the many politicians who made the COVID-19 pandemic outbreak a political stage. Seeing the extraordinary COVID-19 threat and the ineffectiveness of policies taken by the government, the Indonesian government should be even more serious and evaluate the policies that have been taken. The option which is taken by the government is to establish a state of emergency by involving the military in the prevention and handling of the COVID-19 pandemic threat.

Jimly Asshiddiqie in his book Emergency State Administration Law [6] in dealing with danger and facing threats sometimes requires the President to act quickly. One of the conditions that can force the president to determine an emergency status is natural disasters, financial crisis, "financial emergency", war and conflict both at home and abroad as well as the threat of national security and security. In Perpu No. 23 of 1959, a state of danger or emergency was divided according to the category of hazard levels, such as civil emergency, military emergency and war emergency.

In overcoming COVID-19 pandemic the government can establish a civil emergency or military emergency because the COVID-19 pandemic is not only a health problem, but more than it involves economic problems can be seen from the rupiah's plummeting exchange rate, the commodity market conditions of the community's needs begin to be scarce and expensive and information crisis and public trust due to information seemed to overlap with one another.

Determination of the emergency condition, the person responsible for the state of emergency is the President as the Supreme Commander of the State. Meanwhile, the operational implementers in the field are the military 
which is assisted by the Regional Head of the region, the police, and the Prosecutor's Office. To handle COVID-19 will be more guided, neat and organized. Military involvement in the prevention of pandemic COVID-19 as an effort to prevent and minimize the spread of COVID19. If it refers to Indonesia's ability to deal with problems in the event of a surge in COVID-19 patients with inadequate indicators of medical advice and infrastructure and limited medical staff, it is certainly a preventative measure and the most rational option. Therefore, determining the state of emergency whether the government will choose the civil or military emergency option is the most important is the involvement of the military to handle and create conditions for the prevention of COVID-19 is a must. If COVID-19 problem is left to be managed by politicians, prevention and treatment will not be measured and instead become mere political upholders.

An emergency can be enforced at any time when it is needed by the doctrine of "necessity" if there is a need for it. This is contained in article 12 of the 1945 constitution as a "state of danger" and the nature of the substance of 'compelling urgency' which is formulated in article 22 Paragraph (1) of the 1945 Constitution. (The 1945 Constitution of the Republic of Indonesia, nd) If the need ( necessity) referred to indeed exists due to events or potential events that are extraordinary, the Head of State which in this case according to the provisions of the 1945 Constitution is the President and indeed should act to prevent and overcome abnormal conditions. The determination of the enactment of the state of emergency should be conducted by the President as the head of the State according to the provisions of the applicable law, namely Perpu No. 23 of 1959. The considerable power of the President based on the 1945 Constitution affected the delegation of extraordinary powers to the President in Perpu No. 23 of 1959.

The responsibility of declaring a state of danger rests with the President. As a constitution characterized by subjective staatsnoodrecht and subjective noodtoesatandstheorie the judge cannot test the statement of the state of danger committed by the President. According to Perpu No. 23/1959, the position of the high war ruler is no longer under the KSAD but in the hands of the President. In Perpu No. 23 of 1959, a state of danger or emergency was divided according to the category of hazard levels, such as civil emergency, military emergency and war emergency. The exercise of power at each level of the hazard situation differs from one another. However, the person responsible for the emergency is the President as the Supreme Commander of the State.

Meanwhile, the operational implementers in the field, for martial law and martial law, are military rulers, and for civil emergencies are civil emergency rulers. Emergency itself can occur due to various reasons, both natural such as natural disasters Human causes occurred as a result of human activity. Civil emergencies are emergencies where the level of danger is considered to be the lowest in the sense of the least threat of danger. Members of the army or military forces are needed to deal with the situation.

Provisions of article 7 paragraph (1) of Law no. 34 of 2004 concerning the Indonesian Armed Forces, the main task of the Indonesian National Armed Forces (TNI) is to uphold national sovereignty, maintain the territorial integrity of the Unitary State of the Republic of Indonesia based on Pancasila and the 1945 Constitution of the Republic of Indonesia, and protect all nations and all spilled blood. Indonesia from threats and disturbances to the integrity of the nation and state. (Law Number 34 of 2004 concerning the Indonesian Armed Forces, nd) The main task is conducted by military operations for military operations other than war. Operations Likewise can be distinguished between military operations for non-war.

Article 7 Paragraph (2) letters a and b of Law No. 34 Year 34 About the Indonesian National Army determines the difference between the two. Military operations other than war one of which includes efforts to help cope with the effects of natural disasters, displacement, and the provision of humanitarian assistance and assist the task of government in the area. Article 1 Paragraph (1) Perpu No. 23 of 1959, the President / Supreme Commander of the Armed Forces declares all or part of the territory of the Republic of Indonesia is in danger with a degree of civil emergency or military emergency or martial law, if security or law order throughout the territory of the Republic of Indonesia is threatened by rebellion, riots, due to natural disasters or from special circumstances it turns out or feared that there are symptoms can endanger the life of the country for is feared cannot be overcome by ordinary equipment. (Government Regulation instead of Law Number 23 of 1959, n.d.)

The views of the National Commission on Human Rights of the Republic of Indonesia address the acceleration of the handling of the COVID-19 Virus Spread

Human Rights (HAM) are basic rights possessed by humans from birth. Human rights apply at any time, anywhere and to anyone [7]. Ahmad Taufan Damanik as Chairman of the National Commission on Human Rights of the Republic of Indonesia appealed to all Indonesian people to obey and fulfill the calls made by the government, both at the central and central levels regions, to prevent the spread of COVID-19 which is increasingly threatening the people of Indonesia every day. "This relates to the protection and fulfillment of human rights, not only the right to health but also the right to life for Indonesian citizens," Ahmad Taufan Damanik said in a written statement.

Previously the Chairperson of the Indonesian National Commission on Human Rights had met with the Head of the BNPB as the Chair of the COVID-19 Task Force, Lt. Gen. Doni Monardo. The Indonesian National Commission on Human Rights requested the Indonesian government, in this case, the COVID-19 Task Force, take a firm stance by sanctioning anyone in the jurisdiction of the Republic of Indonesia who did not heed the provisions issued by the government, both the central government and the regional government. Include not to gather in large numbers even though it is related to religious worship activities. "International and national human rights standards give authority to the government to limit, reduce or delay human rights related to freedom of assembly and worship in large numbers in the interests of the safety and health of the wider community.

Public health and public safety reference more specifically in the limitation, reduction and postponement of certain human rights, including the right to worship 
which includes large numbers of people, "Ahmad Taufan Damanik said. Strict policies to limit, reduce and delay freedom for the sake of wider public safety and health, not violations of human rights. Therefore, Komnas HAM also proposes when possible or if necessary the Government can issue a Perppu which provides a clearer legal firmness to the public that truly complies with the rules that have been issued. Komnas HAM also asked the government to ensure workers throughout Indonesia, did not experience the threat of layoffs or other workers' rights reduction as a result of the Work From Home policy or as a result of economic problems in the business world with the COVID-19 crisis. The government is also asked to facilitate the needs of formal and informal sector workers to continue to enjoy a decent life.

\section{CONCLUSION}

The problem to handle Corona Virus Disease cannot be done alone by the task force for speeding up COVID19 Doni Monardo et al. Is to break the chain of the spread of the COVID-19 virus, considered almost one month after the issuance of the COVID-19 disaster emergency continues to increase the death rate felt social distancing efforts are still not implemented firmly and disciplined by the people of Indonesia, bearing in mind for the speedy completion of the COVID-19 distribution then it is deemed necessary to immediately determine not only health emergencies but military emergencies to respond to the impact of the acceleration of policy to handle COVID19 distribution, which a very crucial problem occurred chaos economically. Therefore, the presence of the TNI as a state tool is needed to safeguard strategic public sectors which are prone to plunder by communities that cannot be controlled by common sense.

\section{ACKNOWLEDGMENT}

The author would like to the Dean of Faculty of Social Science, Manado State University in supporting the publication of this article.

\section{REFERENCES}

[1] Karjadi, Kitab Undang-Undang Hukum Acara Pidana. Jakarta: Politea, 1981.

[2] M. Fuady, Teori Negara Hukum Modern. Jakarta: Rafika Aditama, 2011.

[3] A. R. Budiono, Pengantar Ilmu Hukum. Jakarta: Bayu Media Publishing, 2005.

[4] P. M. Marzuki, 'Penelitian Hukum'. Prenada Media Group, Jakarta, 2005.

[5] S. Soekanto, Pengantar Penelitian Hukum. Jakarta: UI Press, 1986.

[6] J. Asshiddiqie, 'Konstitusi dan Konstitusionalisme Indonesia'. PT. Syamil Cipta Media, Jakarta, 2006.

[7] Subekti, Perlindungan Hak Asasi Manusia dalam KUHAP. Jakarta: Pradnyana Paramita, 1984. 